\title{
GAMBARAN TINGKAT AKTIVITAS FISIK DAN KEBUGARAN SERTA HUBUNGANNYA PADA MAHASISWA FAKULTAS KEDOKTERAN UNIVERSITAS ALKHAIRAAT PALU TAHUN 2016
}

\author{
Supandri Kango ${ }^{1}$ Indriani $^{1^{*}}$, Achmad Zaifullah ${ }^{1}$ \\ ${ }^{1}$ Program Studi Pendidikan Dokter, Fakultas Kedokteran Universitas Alkhairat, Jl. Diponegoro No. 39 \\ Palu 94221, Sulawesi Tengah, Indonesia
}

"Corresponding author: Telp: +6285292901002 email: Sidney_1484@yahoo.co.id

\begin{abstract}
ABSTRAK
Dokter merupakan profesi yang membutuhkan tingkat kebugaran yang tinggi. Tingkat kebugaran yang tinggi dipengaruhi oleh banyak faktor antara lain umur, jenis kelamin, makanan, kebiasaan merokok dan keturunan. Olahraga aktivitas fisik sangat berpengaruh pada kebugaran tetapi menuntut olahraga yang teratur dan berkesinambungan. Tujuan penelitian ini adalah untuk mengetahui tingkat aktivitas fisik dan kebugaran pada mahasiswa Fakultas Kedokteran Universitas Alkhairaat Palu dan membuktikan hubungan antara tingkat aktivitas fisik dengan kebugaran. Metode penelitian ini adalah observasional dengan pendekatan cross sectional study. Diambil 74 orang mahasiswa Fakultas Kedokteran Universitas Alkhairaat secara random sederhana dari 292 mahasiswa fase akademik. Besar sampel ditentukan berdasarkan rumus Slovin. Penenentuan tingkat aktivitas fisik berdasarkan kuesioner Baecke dan dilakukan pengukuran tingkat kebugaran berdasarkan Harvard step tes. Dilakukan analisis deskriptif dan uji hipotesis dengan uji korelasi chi square pada batas kemaknaan 5\%. Hasil penelitian, (1). Didapatkan Mahasiswa yang bugar $(85,1 \%)$ dan yang tidak bugar (14,9\%). (2). Didapatkan Mahasiswa yang aktif dalam menjalankan aktivitas fisik $(63,5 \%)$ dan yang tidak aktif $(36,5 \%)$. (3). Terdapat hubungan yang bermakna antara aktivitas fisik dengan kebugaran $\mathrm{p}=0.00$. Kesimpulan penelitian adalah terdapat hubungan antara aktivitas fisik dengan kebugaran mahasiswa Fakultas Kedokteran Universitas Alkhairaat palu tahun 2016.
\end{abstract}

Kata Kunci : Aktivitas fisik, kebugaran, tingkat kebugaran

\section{ABSTRACT}

Doctors are professions that require a high level of fitness. A high level of fitness is influenced by many factors including age, gender, food, smoking habits and offspring. Sports physical activity is very influential on fitness but demands regular and regular exercise. The purpose of this study was to determine the level of physical activity and fitness of students of the Medical Faculty of Alkhairaat University in Palu and prove the relationship between the level of physical activity and fitness. The method of this study was observational with a cross sectional study approach. 74 students from the Medical Faculty of Alkhairaat University took a simple random out of 292 academic phase students. Sample size is determined based on Slovin formula. Determining the level of physical activity based on the Baecke questionnaire and measuring fitness level based on the Harvard step test. Descriptive analysis and hypothesis testing using the chi square correlation test at the significance limit of 5\% were carried out. Research results, (1). Obtained students who are fit (85.1\%) and who are not fit (14.9\%). (2). Students are active in carrying out physical activities (63.5\%) and those who are not active (36.5\%). (3). There is a significant relationship between physical activity and fitness $p=0.00$. The conclusion of the study is that there is a relationship between physical activity and fitness of students of the Medical Faculty of Alkhairaat University hammer in 2016.

Keywords: Physical activity, fitness, fitness level 


\section{PENDAHULUAN}

Kebugaran jasmani adalah kemampuan tubuh seseorang untuk melakukan tugas sehari-hari tanpa menimbulkan kelelahan yang berarti, sehingga tubuh masih memiliki cadangan tenaga untuk mengatasi beban tambahan ${ }^{1,2}$.

Aktivitas fisik menurut WHO adalah setiap gerakan tubuh yang dihasilkan oleh otot rangka yang memerlukan pengeluaran energi. Aktivitas fisik yang tidak ada (kurangnya aktivitas fisik) merupakan faktor resiko independen untuk penyakit kronis, dan secara keseluruhan diperkirakan menyebabkan kematian secara global ${ }^{3,4}$.

Tingkat kebugaran seseorang di Amerika serikat yang rajin berolahraga sebesar $48,5 \%$, yang tidak rajin berolahraga $39 \%$ sementara tingkat kebugaran di Brazil pada pria $8 \%$ baik, $76 \%$ buruk sedangkan pada wanita $12,2 \%$ baik, $70,8 \%$ buruk $^{5}$. Tingkat aktivitas fisik di Skotlandia sebesar $21 \%$ masih rendah dan di Wales tingkat aktivitas fisik pada pria lebih rendah $36 \%$ dibanding wanita $23 \%$ rendah $^{6}$.

Seiring dengan berkembangnya ilmu pengetahuan dan teknologi yang serba modern seperti saat ini, transportasi dengan menggunakan kendaraan, pemakaian alatalat yang menghemat tenaga kerja, dan aktivitas kurang gerak demi kenyamanan hidup seperti menonton televisi sampai ketingkat yang jauh lebih rendah maka aktivitas yang seharusnya membutuhkan aktivitas fisik yang besar kini dapat dilakukan dengan mudah dan sedikit gerak. Berbagai sarana menyebabkan gerak dan aktivitas menjadi semakin terbatas dan hidup semakin santai karena segalanya sudah tersedia sehingga dapat menimbulkan penyakit kurang gerak seperti tubuh tambun atau berkadar lemak tinggi, penderita cenderung mengidap penyakit berbahaya seperti jantung, paru-paru dan ginjal, tekanan darah tinggi dan gangguan pencernaan $^{4,7}$. Penelitian yang dilakukan oleh Yhusi K. Riskawati et al di Fakultas Kedokteran Universitas Brawijaya, yang menyimpulkan bahwa tingkat aktivitas fisik mahasiswa kedokteran masih tergolong rendah $(60 \%)^{8}$.

$\begin{array}{rrr}\text { Berdasarkan } & \text { dampak yang } \\ \text { ditimbulkan dan } & \text { data } & \text { diatas }\end{array}$
memperlihatkan bahwa masih rendahnya kesadaran seseorang untuk melakukan aktivitas khususnya di Sulawesi tengah dan juga sangat berpengaruh terhadap kebugaran mahasiswa itu sendiri menjadi alasan penyusunan penelitian ini yakni bagaimana gambaran tingkat aktivitas fisik dan kebugaran serta hubungannya pada mahasiswa Fakultas Kedokteran Universitas Alkhairaat Palu tahun 2016.

\section{METODOLOGI}

Desain penelitian ini adalah observasional dengan menggunakan pendekatan cross sectional. Penelitian ini dilakukan pada tahun 2016 di Universitas Alkhairaat Palu. Populasi penelitian adalah mahasiswa Fakultas Kedokteran Universitas Alkhairaat Palu. Subyek penelitian adalah mahasiswa Fakultas Kedokteran Universitas Alkhairaat Palu yang memenuhi kriteria inklusi. Kriteria Inklusi penelitian adalah mahasiswa Fakultas Kedokteran Universitas Alkhairaat Palu, mahasiswa yang Sehat jasmani dan rohani dan setuju ikut penelitian tanpa ada paksaan. Kriteria Ekslusi penelitian adalah mahasiswa yang menderita penyakit jantung, mahasiswa yang menderita penyakit paru-paru, dan mahasiswa yang menderita obesitas.

Jumlah sampel yang dibutuhkan adalah 74 orang. Cara pengambilan sampel menggunakan proporsional stratified random sampling yaitu teknik pengambilan 
sampel dimana semua angkatan memiliki keterwakilan untuk dijadikan sampel penelitian. Analisis dan interpretasi data dengan menggunakan program komputer SPSS 18.

\section{HASIL DAN PEMBAHASAN}

Dari 74 sampel hasil analisis data disajikan dalam sistematika sebagai berikut :

Tabel 1. Distribusi penelitian berdasarkan karakteristik sampel

\begin{tabular}{|c|c|c|c|}
\hline & Variabel & $\mathrm{N}$ & $\%$ \\
\hline \multicolumn{4}{|c|}{ Umur } \\
\hline - & 18 & 9 & 12,2 \\
\hline - & 19 & 13 & 17,6 \\
\hline - & 20 & 17 & 23,0 \\
\hline - & 21 & 22 & 29,7 \\
\hline - & 22 & 5 & 6,8 \\
\hline - & 23 & 4 & 5,4 \\
\hline - & 24 & 4 & 5,4 \\
\hline \multicolumn{4}{|c|}{ Angkatan } \\
\hline - & 2012 & 17 & 23,0 \\
\hline - & 2013 & 24 & 32,4 \\
\hline - & 2014 & 13 & 17,6 \\
\hline - & 2015 & 13 & 17,6 \\
\hline - & 2016 & 7 & 9,5 \\
\hline \multicolumn{4}{|c|}{ Jenis Kelamin } \\
\hline- & Laki-laki & 23 & 31,1 \\
\hline- & Perempuan & 51 & 68,9 \\
\hline
\end{tabular}

Berdasarkan tabel 1, untuk umur 18 tahun $(12,2 \%)$, umur 19 tahun $(17,6 \%)$, umur 20 tahun $(23,0 \%)$, umur 21 tahun $(29,7 \%)$, umur 22 tahun $(6,8 \%)$, umur 23 tahun $(5,4 \%)$, umur 24 tahun $(5,4 \%)$. sehingga total (100\%), dari 74 subyek angkatan 2012 (23,0\%), angkatan 2013 (32,4\%), angkatan 2014 (17,6\%), angkatan 2015 (17,6\%), angkatan 2016 (9,5\%) sehingga total $100 \%$, dari 74 subyek jenis kelamin pria $(31,1 \%)$ lebih sedikit dibanding jenis kelamin wanita $(68,9 \%)$ sehingga total $100 \%$.

Tabel 2. Distribusi sampel berdasarkan tingkat kebugaran

\begin{tabular}{ccc}
\hline Kebugaran & $\mathrm{N}$ & $\%$ \\
\hline Bugar & 63 & 85,1 \\
Tidak Bugar & 11 & 14,9 \\
\hline Total & 74 & 100 \\
\hline
\end{tabular}

Berdasarkan tabel 2, bahwa mahasiswa yang bugar 63 orang $(85,1 \%)$ dan mahasiswa yang tidak bugar 11 orang $(14,9 \%)$.

Tabel 3. Distribusi sampel berdasarkan tingkat aktivitas fisik

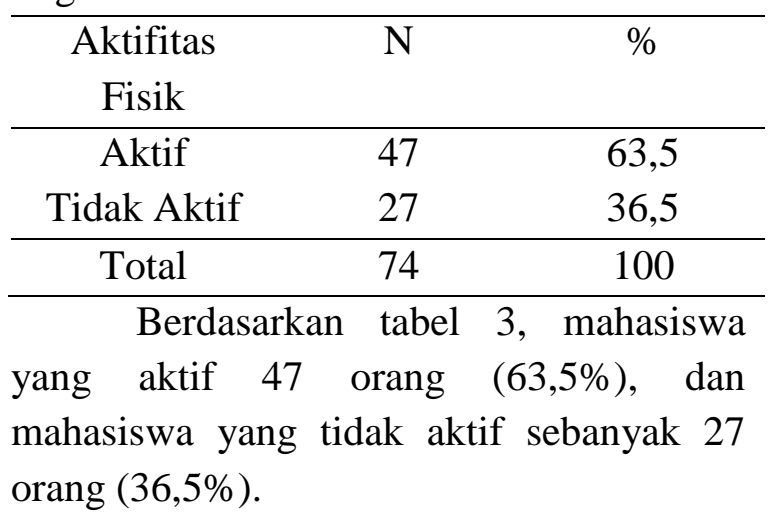

Tabel 4. Hubungan aktivitas fisik dengan kebugaran

\begin{tabular}{ccccc}
\hline & & \multicolumn{2}{c}{ Kebugaran } & \\
\cline { 3 - 4 } & & Bugar & Tidak Bugar & Total \\
\hline \multirow{3}{*}{$\begin{array}{c}\text { Aktivitas } \\
\text { Fisik }\end{array}$} & Aktif & 47 & 0 & 47 \\
& & $(100.0 \%)$ & $(0 \%)$ & $100.0 \%$ \\
& \multirow{2}{*}{ Tidak Aktif } & 16 & 11 & 27 \\
& & $(59.3 \%)$ & $(40.7 \%)$ & $100.0 \%$ \\
\hline \multicolumn{2}{c}{ Total } & 63 & 11 & 74 \\
\hline
\end{tabular}




\begin{tabular}{|c|c|c|c|c|}
\hline & & \multicolumn{2}{|c|}{ Kebugaran } & \multirow[b]{2}{*}{ Total } \\
\hline & & Bugar & Tidak Bugar & \\
\hline \multirow{4}{*}{$\begin{array}{c}\text { Aktivitas } \\
\text { Fisik }\end{array}$} & & 47 & 0 & 47 \\
\hline & Aktıf & $(100.0 \%)$ & $(0 \%)$ & $100.0 \%$ \\
\hline & \multirow{2}{*}{ Tidak Aktif } & 16 & 11 & 27 \\
\hline & & $(59.3 \%)$ & $(40.7 \%)$ & $100.0 \%$ \\
\hline \multirow{2}{*}{\multicolumn{2}{|c|}{ Total }} & 63 & 11 & 74 \\
\hline & & $85.1 \%$ & $14.9 \%$ & $100.0 \%$ \\
\hline
\end{tabular}

$\mathrm{p}=0,00$ diperoleh dengan uji chi square

Dari tabel 8 dapat dilihat bahwa ada hubungan yang bermakna $(\mathrm{p}<0,05)$ antara aktivitas fisik dengan kebugaran. Tingkat kebugaran mahasiswa Fakultas Kedokteran Universitas Alkhairaat Palu yang berkategori bugar sebagian besar terdapat pada mahasiswa yang memiliki aktivitas fisik yang berkategori aktif, sedangkan yang tidak bugar lebih banyak ditemukan pada mahasiswa dengan kategori aktivitas fisik yang tidak aktif.

\section{PEMBAHASAN}

Gambaran antara tingkat aktivitas fisik dengan kebugaran, menunjukkan ada hubungan yang bermakna $(\mathrm{p}<0,05)$. Hasil penelitian berdasarkan tingkat aktivitas fisik diperoleh $63,5 \%$ tidak sejalan dengan penelitian yang dilakukan oleh Yhusi K. Riskawati et al di Fakultas Kedokteran Universitas Brawijaya, yang menyimpulkan bahwa tingkat aktivitas fisik mahasiswa kedokteran masih tergolong rendah $60 \%$. Hal ini mungkin disebabkan karena kurikulum mahasiswa fakultas kedokteran Universitas Alkhairaat Palu lebih padat sehingga tingkat aktifitas fisiknya tergolong sedang-tinggi. Hubungan antara tingkat aktivitas fisik dengan kebugaran terletak pada komponen kebugaran yaitu daya tahan kardiorespirasi. Daya tahan kardiorespirasi merupakan daya tahan yang menggunakan kemampuan $\mathrm{O}_{2}$ untuk bekerja yang disebut daya tahan aerobik atau yang dikenal dengan nama $\mathrm{VO}_{2} \max . \mathrm{VO}_{2} \max$ ini dipengaruhi oleh 3 komponen penting yaitu sistem pernafasan. Konsumsi oksigen dan ventilasi paru seseorang meningkat pada saat istirahat dan latihan dengan intensitas maksimal. Karena ketika seseorang melakukan suatu aktivitas fisik maka akan terjadi proses difusi oksigen dan alveoli paru agar oksigen tersebut bisa masuk dan diedarkan ke seluruh tubuh oleh karena itu, kapasitas pernapasan maksimum lebih besar daripada ventilasi paru seseorang selama latihan. Hal ini membuktikan bahwa sistem pernapasan bukanlah faktor pembatas yang sesungguhnya. Komponen kedua adalah sistem kardiovaskular. Pada sistem kardiovaskular ada 3 hal yang saling berhubungan yaitu curah kerja otot, konsumsi oksigen dan curah jantung yang saling berhubungan satu sama lain. Curah Kerja otot akan meningkatkan konsumsi oksigen dan oksigen yang dikonsumsi akan melebarkan pembuluh darah otot, sehingga meningkatkan aliran balik vena dan curah jantung yang akan berefek pada peningkatan ruang dan massa jantung dan curah jantung yang dipengaruhi oleh isi sekuncup dan frekuensi denyut jantung yang dicapai sekitar $95 \%$ dari tingkat maksimal maka sistem kardiovaskular merupakan pembatas nilai $\mathrm{VO}_{2}$ max. Komponen yang ketiga adalah kadar sel 
darah merah (hemoglobin) karena jika kadar sel darah merah seseorang dibawah kadar yang normal maka tentunya oksigen yang disuplai tidak akan mencukupi kebutuhan jaringan untuk melakukan aktivitas fisik.

\section{KESIMPULAN}

Berdasarkan penelitian yang dilakukan bahwa terdapat hubungan antara aktivitas fisik dengan kebugaran mahasiswa Fakultas Kedokteran Universitas Alkhairaat Palu tahun 2016. Mahasiswa yang bugar lebih banyak ditemukan pada mahasiswa yang mempunyai tingkat aktivitas fisik yang berkategori aktif sedangkan mahasiswa yang tidak bugar lebih banyak ditemukan pada mahasiswa yang mempunyai tingkat aktivitas fisik yang berkategori tidak aktif.

\section{DAFTAR PUSTAKA}

1. Rizki R. 2014. Hubungan antara Status Gizi dan Kebiasaan Berolahraga dengan Tingkat Kebugaran Jasmani. Jurnal Pendidikan Olahraga dan Kesehatan, Vol 2, No. 1, 30-33.

2. Suharjana F. 2011. Membina Kebugaran Jasmani Anak dengan Senam Pembentukan. MEDIKORA, Vol 3, No.1, 77-86.

3. Angraini D. 2014. Hubungan Indeks Massa Tubuh, Aktivitas Fisik, Rokok, Konsumsi Buah, Sayur dan Kejadian Hipertensi pada Lansia di Pulau Kalimantan. Fakultas Ilmu - ilmu Kesehatan Universitas Esa Unggul.

4. Sutri. 2014. Hubungan Aktivitas Fisik dengan Kesegaran Jasmani pada Remaja Puasa. Universitas Muhammadiyah Surakarta.
5. Bosch, TA, et al. 2015.Fitness Level is Associated with sex-specific Regional Fat Differences.

6. Eastwood, P. 2014. Statistics on Obesity, Physical Activity and Health and Social Care Information Centre.

7. Lathiifa H. 2009. Gambaran Kebiasaan Berolahraga Terhadap Daya Tahan Kardiorespirasi pada Siswa-siswi SMU Triguna Utama. Universitas Islam Negeri Syarif Hidayatullah Jakarta.

8. Riskawati Yhusi. K, Prabowo Edwin. D, Al Rasyid Harun. Tingkat Aktivitas Fisik Mahasiswa Program Studi Pendidikan Dokter Tahun Kedua, Ketiga, Keempat. Fakultas Kedokteran Universitas Brawijaya. 2018;5(01), 2632 